\title{
Efficacy of chemical and biological strategies for controlling the soybean brown spot (Septoria glycines)
}

\author{
Jorge D. Mantecón ${ }^{1}$ \\ Facultad de Ciencias Agrarias, Universidad Nacional de Mar del Plata, and Departamento de Agronomía, \\ Estación Experimental Agropecuaria, Instituto Nacional de Tecnología Agropecuaria (INTA), Balcarce, \\ Argentina. c.c.276, 7620 Balcarce, Buenos Aires, Argentina.
}

\begin{abstract}
J.D. Mantecón. 2008. Efficacy of chemical and biological strategies for controlling the soybean brown spot (Septoria glycines). Cien. Inv. Agr. 35(2):211-214. Soybean (Glycine max) is currently the most widely grown and rapidly expanding crop in Argentina, and brown spot caused by Septoria glycines is a major foliage disease that affects this crop. Trials in the 2005 and 2006 growing seasons were undertaken using soybean (Glycine max) cv. Nidera A4800 RR. A randomized complete block design was used with four replicates. Two biological fungicides, based on Bacillus subtilis or B. pumilus, and four conventional fungicides, pyraclostrobin in combination with epoxiconazole (Opera 25 SC, BASF Argentina), azoxystrobin (Amistar 25 SC, Syngenta Argentina), trifloxystrobin in combination with cyproconazole (Sphere 267,5 EC, Bayer, Argentina), and tebuconazole (Folicur 25 EC, Bayer, Argentina), were evaluated. Fungicides were applied at the R3 stage of soybean development. The effectiveness of the fungicide was determined by measuring disease incidence and severity. High doses of biological fungicides and all chemical treatments reduced the incidence of disease compared to the untreated control, but only Bacillus subtilis QST 713 at a high dose showed a similar efficacy for reducing disease severity. The best results for reducing disease incidence and severity were obtained with the strobilurin fungicides pyraclostrobin plus epoxiconazole, trifloxystrobin plus cyproconazole, and azoxystrobin. The best yields were obtained with chemical and biological treatments at high doses applied at R3; these treatments appeared to have a direct relationship with reduced development of foliar symptoms.
\end{abstract}

Key words: Bacillus, chemical and biological control, brown spot, diseases, fungicides, soybean.

\section{Introduction}

Soybean (Glycine $\max$ L.) is currently the most widely grown and rapidly expanding crop in Argentina. During the last agricultural season, the crop accounted for more than $50 \%$ of all grain production in the country. Soybean has sharply replaced traditional crops, such as cotton and rice, in the northeast part of Argentina (Vallone and Giorda, 1997). Under Argentinean climatic conditions, diseases of soybean are relatively unimportant during the early growing stages, but environmental factors

Received 11 December 2007. Accepted 07 February 2008. 1'Corresponding author: jmantecon@balcarce.inta.gov.ar usually favor disease development during the reproductive stages of soybeans (Carmona et al., 2003).

The considerable increase in soybean plantings has increased the importance of this crop, and soybean diseases have gradually increased (Sinclair and Backman, 1989). Disease caused an estimated loss of $8 \%$ of the national production in 1996. However, losses have increased to $10 \%$ in the last season due to favorable climatic conditions and to the absence of crop rotation.

The brown leaf spot (Septoria glycines Hemmi) can appear at the seedling stage shortly after planting, but it becomes more severe when it occurs near maturity. This disease is one of the 
most important of the so-called end-of-cycle complex, causing considerable damage at the late soybean growth stages. It must be taken into account, however, that its presence in the initial stages determines its severity during the final stages of the soybean crop. Therefore, the higher the disease incidence and severity at early vegetative stages, the higher is the disease incidence and damage at maturity. Damages can include premature defoliation, a shortened life-cycle, and yield loss. In Argentina, chemical control of the end-of-cycle complex of soybeans has been adopted, increasing yields from 10 to 25\% (Mantecón, 2005a,b; 2006a,b). The objective of this study was to evaluate the efficacy of biological and chemical strategies for controlling the soybean brown spot.

\section{Materials and methods}

\section{Soybean crop}

Trials were carried out using soybean cv. Nidera A4800 RR seeded in a Brunizen soil with 4.2\% of organic matter, Buenos Aires province, Argentina in 2005 and 2006. Seed was sown using a low direct seeding system. The crop was irrigated as needed, using sprinklers for a total of $240 \mathrm{~mm}$ in the 2005 and $180 \mathrm{~mm}$ in the 2006 growing season.

\section{Fungicides and biological agents}

Two biological fungicides were used: Bacillus subtilis (Serenade Max, QST 713) and $B$. pumilus (Sonata ASO, QST 2808), formulated by AgraQuest, Inc. USA. Several chemical fungicides were used: pyraclostrobin in combination with epoxiconazole (Opera 25 SC, BASF Argentina), azoxystrobin (Amistar 25 SC, Syngenta Argentina), trifloxystrobin in combination with cyproconazole (Sphere 267,5 EC, Bayer, Argentina), and tebuconazole (Folicur 25 EC, Bayer, Argentina). Soybean crops were sprayed at the R3 stage (19 Jan 2005, and $03 \mathrm{Feb} 2006$ ), using $150 \mathrm{~L}^{\mathrm{h}} \mathrm{ha}^{-1}$ with a $\mathrm{CO}_{2}$-pressurized backpack sprayer equipped with four ceramic disc-type cone nozzles spaced $0.3 \mathrm{~m}$ apart. Disease incidence and severity were evaluated at 30 and 50 days after fungicide application. Incidence was evaluated using the Hershman scale (1999) for soybeans, where $0=$ no foliage symptoms, $1=$ symptoms in lowest foliage, $2=$ lowest foliage symptoms in all plants and symptoms in upper foliage in some plants with short defoliation, and 3 = upper foliage symptoms in all plants with severe defoliation. Severity was evaluated by the proportion of diseased leaf area using the Martins et al. (2004) scale. Yields were determined in each growing season.

\section{Design and statistical analysis}

In both growing seasons, treatments were distributed according to a randomized complete block design with four replicates; the experimental units consisted of four $5 \mathrm{~m}$ long rows spaced $0.51 \mathrm{~m}$ apart. Data were analyzed for variance, and means were separated by the least significant difference test (LSD) at $\mathrm{p}=$ 0.05 .

\section{Results and discussion}

The environmental conditions during the trials were favourable for the development of soybean brown spot, with cool temperatures (day mean about $20^{\circ} \mathrm{C}$ ), high relative humidity $(70-80 \%)$, and weekly rains. In addition, the irrigation possibly promoted infection.

In both seasons, symptoms of brown spot appeared early in the growing season on maturing crops. Severe infections were characterized by yellow leaves that dropped early, especially lower leaves in the canopy (Yang, 2003). The untreated controls showed severe defoliation, but a complete defoliation was not observed. In the 2005 growing season (Table 1), pyraclostrobin plus epoxiconazole (Opera 25SC), azoxystrobin (Amistar 25SC) and trifloxystrobin plus cyproconazole (Sphere 267,5EC) significantly $(\mathrm{p}=0.05)$ reduced disease incidence compared to the untreated controls and the control obtained with $B$. subtilis at the highest doses. Additionally, all chemical treatments were most effective in reducing disease severity. The best inhibition of disease was obtained with pyraclostrobin plus epoxiconazole, cyproconazole plus trifloxystrobin, and azoxystrobin applied at the R3 stage of soybean. The degree of disease control obtained with tebuconazole, a triazol 
Table 1. Effect of chemical and biological control on incidence and severity brown spot (Septoria glycines) and yields of soybean (Glycine max).

\begin{tabular}{|c|c|c|c|c|c|}
\hline \multirow[t]{2}{*}{ Treatments/rate ${ }^{2}, \mathrm{~L} \cdot \mathrm{ha}^{-1}$} & \multicolumn{2}{|c|}{$\begin{array}{l}\text { Incidence }{ }^{1} \\
\text { scale } 0 \text { to } 3\end{array}$} & \multicolumn{2}{|c|}{$\begin{array}{c}\text { Severity } \\
\% \\
\end{array}$} & \multirow[t]{2}{*}{$\begin{array}{l}\text { Yield, } \\
\mathrm{t} \cdot \mathrm{ha}^{-1}\end{array}$} \\
\hline & $02 \mathrm{Feb}$ & $09 \mathrm{Mar}$ & $18 \mathrm{Feb}$ & $09 \mathrm{Mar}$ & \\
\hline & \multicolumn{5}{|c|}{ Growing season: 2005} \\
\hline Untreated control & $2.0 \mathrm{a}^{3}$ & $3.0 \mathrm{a}^{3}$ & $15.0 \mathrm{a}^{3}$ & $25.0 \mathrm{a}^{3}$ & $3.7 c^{3}$ \\
\hline Bacillus subtilis, 1.0 & $2.0 \mathrm{a}$ & $3.0 \mathrm{a}$ & $2.5 \mathrm{~b}$ & $25.0 \mathrm{a}$ & $3.9 \mathrm{bc}$ \\
\hline 2.0 & $2.0 \mathrm{a}$ & $3.0 \mathrm{a}$ & $2.5 \mathrm{~b}$ & $25.0 \mathrm{a}$ & $4.1 \mathrm{bc}$ \\
\hline 4.0 & $1.0 \mathrm{~b}$ & $2.0 \mathrm{ab}$ & $2.5 \mathrm{~b}$ & $2.5 \mathrm{c}$ & $4.4 \mathrm{ab}$ \\
\hline Bacillus pumilus, 1.0 & $2.0 \mathrm{a}$ & $3.0 \mathrm{a}$ & $2.5 \mathrm{~b}$ & $25.0 \mathrm{a}$ & $4.1 \mathrm{bc}$ \\
\hline 2.0 & $2.0 \mathrm{a}$ & $3.0 \mathrm{a}$ & $2.5 \mathrm{~b}$ & $25.0 \mathrm{a}$ & $4.0 \mathrm{bc}$ \\
\hline 4.0 & $1.0 \mathrm{~b}$ & $2.0 \mathrm{ab}$ & $2.5 \mathrm{~b}$ & $15.0 \mathrm{~b}$ & $4.3 \mathrm{abc}$ \\
\hline Pyraclostrobin + epoxiconazole, 0.5 & $0.0 \mathrm{c}$ & $1.0 \mathrm{~b}$ & $0.0 \mathrm{~b}$ & $2.5 \mathrm{c}$ & $4.8 \mathrm{a}$ \\
\hline Trifloxystrobin + cyproconazole, 0.3 & $0.0 \mathrm{c}$ & $1.0 \mathrm{~b}$ & $0.0 \mathrm{~b}$ & $2.5 \mathrm{c}$ & $4.7 \mathrm{a}$ \\
\hline Azoxystrobin, 0.3 & $0.0 \mathrm{c}$ & $1.0 \mathrm{~b}$ & $0.0 \mathrm{~b}$ & $2.5 \mathrm{c}$ & $4.5 \mathrm{ab}$ \\
\hline Tebuconazole, 0.5 & $1.0 \mathrm{~b}$ & $2.0 \mathrm{ab}$ & $2.5 \mathrm{~b}$ & $2.5 \mathrm{c}$ & $4.6 \mathrm{ab}$ \\
\hline Formulation & $05 \mathrm{Mar}$ & $25 \mathrm{Mar}$ & $\begin{array}{c}05 \mathrm{Mar} \\
\text { Growing season: } 2006\end{array}$ & $25 \mathrm{Mar}$ & $\begin{array}{l}\text { Yield } \\
\text { thha }\end{array}$ \\
\hline Untreated control & $2.0 \mathrm{a}^{3}$ & $3.0 \mathrm{a}^{3}$ & $25.0 \mathrm{a}^{3}$ & $25.0 \mathrm{a}^{3}$ & $3.02 \mathrm{c}^{3}$ \\
\hline Bacillus subtilis, 1.0 & $2.0 \mathrm{a}$ & $2.0 \mathrm{ab}$ & $15.0 \mathrm{~b}$ & $25.0 \mathrm{a}$ & $3.20 \mathrm{c}$ \\
\hline 2.0 & $2.0 \mathrm{a}$ & $2.0 \mathrm{ab}$ & $15.0 \mathrm{~b}$ & $25.0 \mathrm{a}$ & $3.30 \mathrm{bc}$ \\
\hline 4.0 & $1.0 \mathrm{~b}$ & $1.0 \mathrm{~b}$ & $10.0 \mathrm{~b}$ & $10.0 \mathrm{c}$ & $3.75 \mathrm{ab}$ \\
\hline Bacillus pumilus, 1.0 & $2.0 \mathrm{a}$ & $2.0 \mathrm{ab}$ & $15.0 \mathrm{~b}$ & $25.0 \mathrm{a}$ & $3.22 \mathrm{bc}$ \\
\hline 2.0 & $2.0 \mathrm{a}$ & $2.0 \mathrm{ab}$ & $15.0 \mathrm{~b}$ & $20.0 \mathrm{ab}$ & $3.77 \mathrm{ab}$ \\
\hline 4.0 & $1.0 \mathrm{~b}$ & $1.0 \mathrm{~b}$ & $15.0 \mathrm{~b}$ & $15.0 \mathrm{bc}$ & $3.85 \mathrm{ab}$ \\
\hline Pyraclostrobin + epoxiconazole, 0.5 & $0.0 \mathrm{c}$ & $1.0 \mathrm{~b}$ & $0.0 \mathrm{c}$ & $10.0 \mathrm{c}$ & $3.91 \mathrm{a}$ \\
\hline Trifloxystrobin + cyproconazole, 0.3 & $0.0 \mathrm{c}$ & $1.0 \mathrm{~b}$ & $0.0 \mathrm{c}$ & $10.0 \mathrm{c}$ & $3.89 \mathrm{a}$ \\
\hline Azoxystrobin, 0.3 & $0.0 \mathrm{c}$ & $1.0 \mathrm{~b}$ & $0.0 \mathrm{c}$ & $10.0 \mathrm{c}$ & $3.90 \mathrm{a}$ \\
\hline Tebuconazole, 0.5 & $1.0 \mathrm{~b}$ & $1.0 \mathrm{~b}$ & $10.0 \mathrm{~b}$ & $10.0 \mathrm{c}$ & $3.80 \mathrm{ab}$ \\
\hline
\end{tabular}

${ }^{1}$ Incidence scale ranges from 0 to 3 , where $0=$ no foliage symptoms, $1=$ symptoms in lowest foliage, $2=$ lowest foliage symptoms in all plants and symptoms in upper foliage in some plants with short defoliation, and $3=$ upper foliage symptoms in all plants with severe defoliation (Hershman, 1999). Severity was estimated according to Martins et al. (2004) on a scale from 0 to $66 \%$ diseased leaf area.

${ }^{2}$ Rates based on formulated products were B. subtilis (Serenade Max, QST 713), B. pumilus (Sonata ASO, QST 2808), pyraclostrobin + epoxiconazole (Opera 25 SC), azoxystrobin (Amistar 25 SC), trifloxystrobin + cyproconazole (Sphere 267,5 EC), and tebuconazole (Folicur $25 \mathrm{EC})$.

${ }^{3}$ Means followed by the same letters are not significantly different according to LSD test $(p=0.05)$.

fungicide, was comparable to that obtained with azoxystrobin, a strobilurin fungicide. Similar results were obtained in the 2006 growing season (Table 1). In both years, applications of the biological fungicide $B$. subtilis showed similar results to the chemical fungicides when applied at the highest rate at the R3 stage of development of soybean. The formulation based on $B$. pumilus was less effective than that based on $B$. subtilis for controlling soybean brown spot in 2005. However, in the 2006 growing season, B. subtilis and B. pumilus were similarly effective in controlling disease (differences were not significant). A single application of the biological fungicides at the highest rate during the R3 stage of soybean development was more effective than lower rates of these biological products.

The best yields were obtained with chemical and biological treatments when they were used at their highest rate during the R3 stage of soybean development; these treatments appeared to be associated directly with a reduction of leaf symptoms. The chemical fungicides were more effective in controlling foliar symptoms and seemed to be a better control strategy for reducing crop damage. 
Previous work has shown that chemical treatments reduce disease severity compared to an untreated control sample, but some of them only reduced disease incidence (Mantecón, 2006a). Our biological treatments reduced incidence and severity but had similar control efficiency to that of chemical fungicide sprays; two applications at the R3 and R5 stages at the highest dose were needed (Mantecón, 2006b). In the 2005 and 2006 seasons, biological fungicides showed good disease control in high doses. Nevertheless, chemical fungicides proved more effective in alleviating disease severity than biological fungicides. Increases in yield from biological and chemical treatments in relation to the untreated control reached $29.7 \%$ and $29.5 \%$ in 2005 and 2006, respectively. No symptoms of phytotoxicity were observed with any treatments.

\section{Resumen}

El cultivo de soja (Glycine max) se ha expandido ampliamente y su superficie ha crecido rápidamente en Argentina siendo la mancha marrón, causada por Septoria glycines la enfermedad más comúnmente encontrada afectando este cultivo. Se realizaron ensayos durante las temporadas 2005 y 2006 con el cultivar de soja Nidera A4800 RR. El diseño utilizado fue en bloques completos aleatorizados con cuatro repeticiones. Durante el desarrollo de los ensayos fueron evaluados dos fungicidas biológicos basados en Bacillus subtilis y B. pumilus, y cuatro fungicidas químicos, pyraclostrobin en mezcla con epoxiconazole (Opera 25 SC, BASF Argentina), azoxystrobin (Amistar 25 SC, Syngenta Argentina), trifloxystrobin en mezcla con cyproconazole (Sphere 267,5 EC, Bayer, Argentina), y tebuconazole (Folicur 25 EC, Bayer, Argentina). Los fungicidas fueron pulverizados sobre las parcelas en el estadío R3 del cultivo. La efectividad de los fungicidas fue determinada en función de la incidencia y severidad de la enfermedad. La mayores dosis evaluadas de los fungicidas biológicos y todos los fungicidas químicos redujeron la incidencia de la enfermedad en comparación con el testigo sin pulverizar, pero sólo $B$. subtilis QST 713 en la mayor dosis mostró eficacia similar a los fungicidas químicos en reducir la severidad la enfermedad. Los mejores resultados para reducir la incidencia y severidad de los síntomas foliares se obtuvieron con los fungicidas estrobirulinas pyraclostrobin más epoxiconazole, trifloxystrobin más cyproconazole y azoxystrobin. Los mejores rendimientos se observaron con los fungicidas químicos y altas dosis de biológicos, pulverizados en R3, dado que estos tratamientos mostraron una relación directa en reducir el desarrollo de los síntomas foliares de la enfermedad.

Palabras claves: Bacillus, control biologico, control químico, enfermedades, fungicidas, soya, mancha café.

\section{References}

Carmona, M, L.D. Ploper, P. Grijalva, M. Gally, and D. Barreto. 2003. Enfermedades de fin de ciclo en soja. Guía para su reconocimiento y manejo. Universidad Nacional de Buenos Aires, 20 pp.

Hershman, D.E. 1999. Kentucky Plant Disease Management Guide for Soybeans. Department of Plant Pathology, University of Kentucky, USA.

Mantecón, J.D. 2005a. Timing of fungicide applications for the control of soybean brown spot, 2001. Fungicide and Nematicide Test 60:126.

Mantecón, J.D. 2005b. Control of soybean stem rot with foliar fungicide applications, 2002. Fungicide and Nematicide Test 60:27.

Mantecón, J.D. 2006a. Fungicide applications for the control of soybean brown spot and frogeye leaf spot, 2004. Fungicide and Nematicide Test 61:65.

Mantecón, J.D. 2006b. Biological and chemical fungicide applications for the control of soybean foliar diseases, 2004. Fungicide and Nematicide Test 61:64.

Martins, MC, R.A. Guerzoni, G.M.S. Camara, P. Mattiazzi, S.A. Lourenço, and L. Amorin, 2004. Escala diagramática para a cuantificaçao do complexo de doenças foliares de final de ciclo em soja. Fitopat. Bras. 29:179-184.

Sinclair J.B., and P.A. Backman, 1989. Compendium of Soybean Diseases. Third Ed.. The American Phytopathological Society Press. St. Paul, Minnesota USA, 206 pp.

Vallone, S., and L.M. Giorda, 1997. Enfermedades de la soja en Argentina. INTA Centro Regional Córdoba. EEA Marcos Juárez-EEA Manfredi. Instituto Nacional de Tecnología Agropecuaria (INTA), Argentina.

Yang, X.B. 2003. Soybean brown spot and bacterial blight. Integrated Crop Management 490(18): July 28 . 